\title{
Erratum: New GOLD classification: longitudinal data on group assignment
}

\author{
Ciro Casanova ${ }^{1 *}$, Jose M Marin ${ }^{2,23}$, Cristina Martinez-Gonzalez ${ }^{3}$, Pilar de Lucas-Ramos ${ }^{4}$, Isabel Mir-Viladrich ${ }^{5}$, \\ Borja Cosio ${ }^{6,23}$, German Peces-Barba ${ }^{7,23}$, Miryam Calle-Rubio ${ }^{8}$, Ingrid Solanes-García ${ }^{9}$, Ramón Agüero ${ }^{10}$, \\ Alfredo de Diego-Damia ${ }^{11}$, Nuria Feu-Collado ${ }^{12}$, Inmaculada Alfageme ${ }^{13}$, Rosa Irigaray ${ }^{14}$, Eva Balcells ${ }^{15}$, \\ Antonia Llunel ${ }^{16}$, Juan Bautista Galdiz-Iturri ${ }^{17}$, Margarita Marín ${ }^{18}$, Juan José Soler ${ }^{19,23}$, Jose Luis Lopez-Campos ${ }^{20,23}$, \\ Joan B Soriano ${ }^{21}$, Juan P de-Torres ${ }^{22}$ and the COPD History Assessment In SpaiN (CHAIN) cohort
}

\section{Erratum}

After publication of this work [1], regrettably we noted that there were two errors in the illustrations, which were added when the paper was under revision and inadequately checked.

In Table 1, when describing the BODE data, the median value was 2 , so instead of $\mathrm{BODE}$ index $+4(0-6)$, the correct one is BODE index 2 (0-6).

Figure two was plotted with incorrect percentages. The correct Figure two is shown next (see Figure 1).

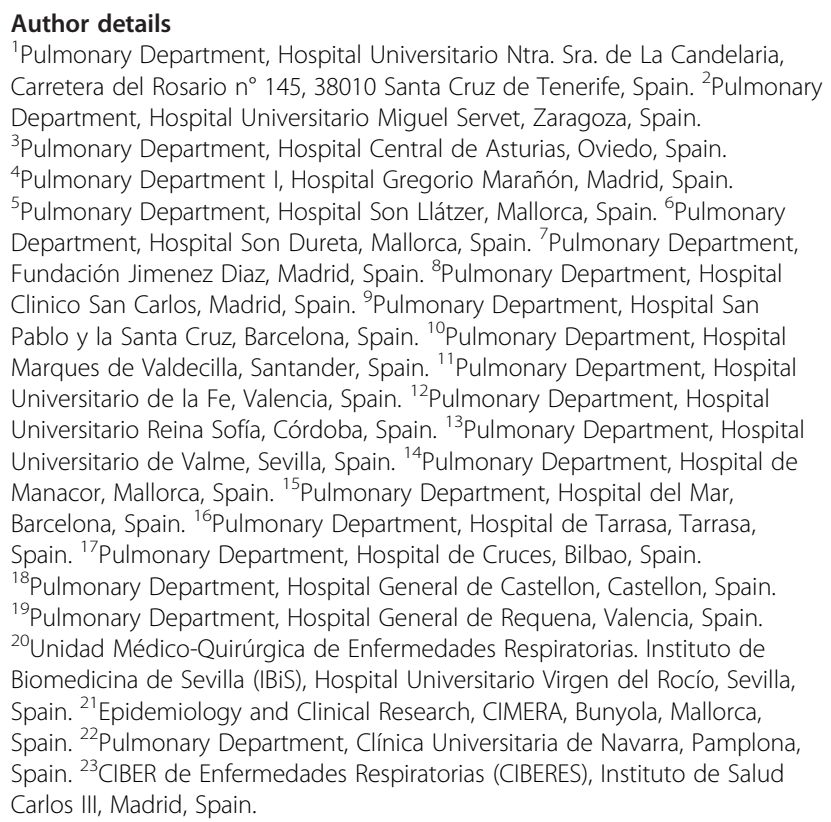

\footnotetext{
* Correspondence: casanovaciro@gmail.com

'Pulmonary Department, Hospital Universitario Ntra. Sra. de La Candelaria, Carretera del Rosario n 145, 38010 Santa Cruz de Tenerife, Spain Full list of author information is available at the end of the article
}

Received: 27 October 2014 Accepted: 27 October 2014

Published online: 11 December 2014

\section{Reference}

1. Casanova C, Marin JM, Martinez-Gonzalez C, de Lucas-Ramos P, Mir-Viladrich I, Cosio B, Peces-Barba G, Calle-Rubio M, Solanes-García I, Agüero R, de DiegoDamia A, Feu-Collado N, Alfageme I, Irigaray R, Balcells E, Llunell A, Galdiz JB, Marín M, Soler-Cataluña JJ, Lopez-Campos JL, Soriano JB, de-Torres JP, COPD History Assessment In SpaiN (CHAIN) Cohort: New GOLD classification: longitudinal data on group assignment. Respir Res 2014, 15:3. doi:10.1186/ 1465-9921-15-3.

\section{doi:10.1186/s12931-014-0140-z}

Cite this article as: Casanova et al:: Erratum: New GOLD classification: longitudinal data on group assignment. Respiratory Research 2014 15:140.

\section{Submit your next manuscript to BioMed Central and take full advantage of: \\ - Convenient online submission \\ - Thorough peer review \\ - No space constraints or color figure charges \\ - Immediate publication on acceptance \\ - Inclusion in PubMed, CAS, Scopus and Google Scholar \\ - Research which is freely available for redistribution

\section{Biomed Central}

(c) 2014 Casanova et al.; licensee BioMed Central Ltd. This is an Open Access article distributed under the terms of the Creative Commons Attribution License (http://creativecommons.org/licenses/by/4.0), which permits unrestricted use, distribution, and reproduction in any medium, provided the original work is properly credited. The Creative Commons Public Domain Dedication waiver (http://creativecommons.org/publicdomain/zero/1.0/) applies to the data made available in this article, unless otherwise stated. 


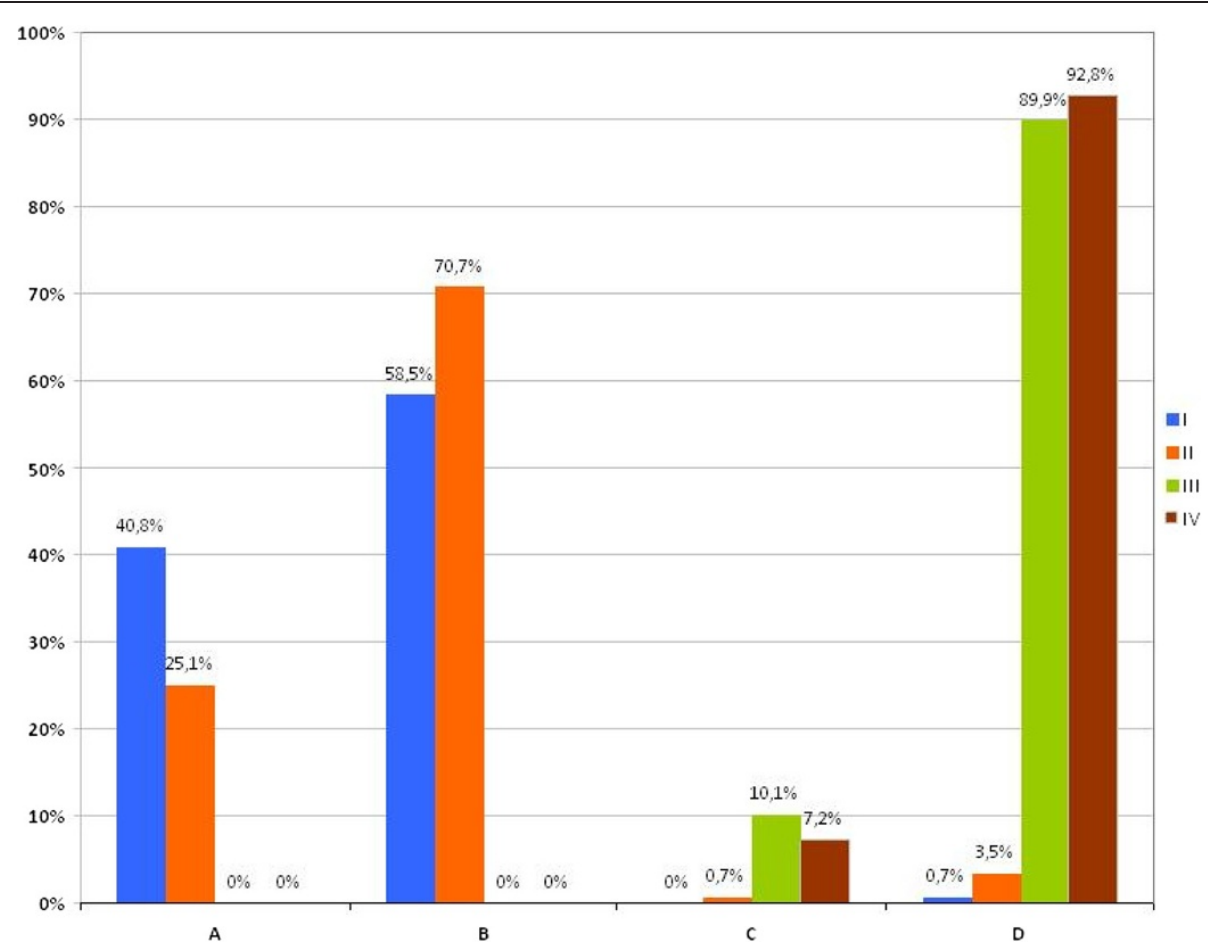

Figure 1 Distribution of patients with COPD at baseline according to GOLD 2007 and GOLD 2013 classification. 